\title{
The Effect of Lactobacillus Casei and Lactobacillus Acidophilus Probiotic Isolates on the Expression of BCL2, BAX and CASPASE3 Genes in Wistar Breeding Rat Albindor to evaluate Gamma Irradiation Induced Apoptosis
}

Vahid Changizi

Tehran University of Medical Sciences

Omid Azadbakht

Behbahan University of Medical Sciences

Pegah Khanzadeh ( $\sim$ khanzadehpegah@gmail.com )

Tehran University of Medical Sciences

\section{Elahe Motevaseli}

Tehran University of Medical Sciences

mohsen shafiee

Abadan University of Medical Sciences

Mehran Nabipour

Mazandaran University of Medical Sciences

\section{Research}

Keywords: Radio protector, Gamma Radiation, Probiotic, Apoptosis, Lactobacillus Casei, Lactobacillus Acidophilus

Posted Date: April 21st, 2020

DOI: https://doi.org/10.21203/rs.3.rs-23354/v1

License: (c) (i) This work is licensed under a Creative Commons Attribution 4.0 International License.

Read Full License 


\section{Abstract}

Background: Radiation therapy is one of the most essential components of cancer treatment, so that more than half of cancer patients receive that treatment modality. Radiotherapy of pelvic, spine, or testicles could cause infertility and oligospermia due to direct effect on the gonads. The testicle, as a high radiosensitive tissue, faces functional disorder with the lowest dose of $0.15 \mathrm{~Gy}$ and oligospermia with 0.3-0.5 Gy. Since protection against adverse effects of Radiation is essential, studies are being done to find out radioprotectors with the non-toxic properties. Probiotics are living microorganisms, the effects of which on the intestinal microbial flora can boost the immune system.

Methods: Male Wistar albino rats were subjected to dietary supplements, including Lactobacillus Casei and Lactobacillus acidophilus, in four groups, for 17 weeks. After being exposed by 2 Gy gamma radiations, the testicular tissue was extracted, and the expression of the apoptotic genes of $\mathrm{Bax}, \mathrm{Bcl} 2$, and Cspase 3 was evaluated.

Results: No significant difference was seen in the expression of Bax, and Bcl24-2 genes among the studied groups. However, Caspase3 expression has increased in the group which hasn't received Radiation but used Lactobacillus Acidophilus.

Conclusion: The present results suggested that the use of the aforementioned probiotics mentioned above would reduce the Radiation-induced apoptosis, which then prevented cell death from oligospermia.

\section{Background}

Production and development of radioprotectors are regarded as essential branches of radiobiology[1]. Disastrous effects of radiation on biological systems are shown through various mechanisms[2, 3]. A range of strategies have been implemented to protect natural systems by using chemical protectors to prevent radiation damage, because radiation-induced normal tissue toxicity is still dose-limiting in patients undergoing radiotherapy[4].

Radiation therapy is a double-edged sword that has been proven to be a palliative therapy for solid tumors[5]. It is estimated that about 50 to 70 percent of all oncology patients are treated with radiation therapy, or a combination of chemotherapy and radiation therapy[6], Although this method has become one of the most important treatments for cancer, the detrimental effects of new defects and late effects on healthy tissues around the body would limit the amount of radiation exposure that can be applied. The beneficial and harmful effects of therapeutic applications of ionizing radiation on living systems are attributed to the production of free radicals [7]. Many of the losses of ionizing radiation in the biological system are mainly due to the indirect effects of radiation[8]. Radiotherapy of pelvis, spine, or testicles has shown to have a direct impact on the gonads, resulting in infertility and steroid hormone production disorders[9]. 
Cancer treatment by either radiotherapy or chemotherapy reduces the number of sperm, often to the level of azoospermia, which can last up to several years[2]. The testicle is one of the most radiosensitive tissues, with the lowest dose of $0.15 \mathrm{~Gy}$ impairs its function, and 0.3-0.5 Gy leads to oligospermia[9].

Most studies in this area have included rodents, because they show fundamental patterns that help to understand the kinetics of improving spermatogenesis in men [10]. The period of reduction in the number of sperm can be identified by the sensitivity of the primary cells. The recovery from azoospermia is highly variable, depending on both the killing of base cells and the change in the physical environment that generally supports the differentiation of the base cells[11]. Radiation and most alkylated substances are potent at producing long-term azoospermia. When being exposed by ionizing radiation, primary damage of the mouse's testicle causes depression in sperm count after the spermatogonia differentiating, the time course of which is around 4 to 5 weeks in mice[12]. The process of spermatogenesis in humans is very similar to that in mice. Although it has been shown that spermatogonia are more sensitive in humans compared to mice[12], Therefore, the result of The present study, which has been done in mice, can be generalized to humans[13]. This fact that spermatogenesis of type A (testicular germ cell lines) seem to be sensitive to radiation is a reflection of the effect of spermatozoa. Similar studies have shown the impact of ionizing radiation on DNA as well as reduced blastocyst growth in mice[14]. Based on their results, sperm DNA and chromosomal abnormalities of sperm in humans are associated with reduced fertility.

The human body partial exposure to the dose of radiotherapy in cancer patients can result in cell death in healthy tissues as well. After being exposed by radiation and passing gap 1 phase cell-cycle, If the cell doesn't consider the repair to be effective, then the cell progresses to the second death checkpoint (G2 arrest), followed by the release of mitochondrial Caspases and death. The B-cell lymphoma 2 (Bcl-269) family of proteins are the guardians of this checkpoint[15]. The Bcl-2 protein is placed in the cover of core and mitochondria, and; it functions through the connection to Bax[16]. It encodes a protein that blocks programmed cell death[17]. The Bax protein in terms of structural is $\mathrm{Bcl}-2$ homologous, and it is considered to be a promoter of apoptosis that is placed in the cytoplasm or the cellular membrane. Hence, in terms of performance, this antagonist protein has a protective role for $\mathrm{Bcl}-2$ The Caspase molecules are generated in the form of prefabricating and just after receiving a death signal by cell, they are activated[18].

A radioprotector is a component that significantly reduces the harmful effects of radiation when exposed to humans or animals before exposure or immediately after radiotherapy[19]. Since the introduction of cysteine as a protective drug in 1949, various chemical, synthetic, and natural ones, have been tested for their various protective effects on different biological systems[13]. A cording to authors' knowledge, only two radioprotective compounds of amifostine and palifermin, are currently FDA approved for use in radiation therapy. However, some other agents that have been reported to show therapeutic promise[20]. Amifostine protects against radiation; however, it is relatively toxic and, its typical side effects include nausea, vomiting, and hypotension[21]. As a result, researchers are still searching for a more capable radioprotector, Which is not only inexpensive and more effective, but also has lower side effects[22]. 
Probiotics are defined by the World Health Organization to be "living organisms" that produce beneficial effects on host health through modulating the intestinal microbial flora[23]. These live and specific microorganisms, when used in humans or animals, affect the body's fluorocarbons of beneficial effects on host health. The live organism and the lactic acid-producing bacteria, in particular, have been used in foods to improve human health from the distant past. The Roman historian, $76 \mathrm{BC}$, recommended the use of milk fermentation products to treat gastroenteritis[24]. There is also data supporting the fact that these beneficial bacteria play a valuable role in the treatment or prevention of radiation hazards[25].

As the development of safe and effective radioprotectors that protect healthy tissues following radiation exposure is highly stressed, in The present study, we Are going to find out the effects of Lactobacillus Casei and Bacillus acidophilus probiotics on protection against radiation.

\section{Materials And Methods}

\section{Preparation and Classifying Animals}

Male albino Wistar rats weighing $220 \pm 20 \mathrm{~g}$ were purchased from an Animal laboratory of Tehran University of Medical Sciences. The animals were kept at $22 \pm 2{ }^{\circ} \mathrm{C}$ and $55 \pm 5 \%$ humidity. Standard feeding, and 12-hour light/ 12-hour dark cycle were used. These animals had access to enough water and food, except the time they were taking drugs. The Ethics Committee approved the protocols used in this study of Tehran University of Medical Sciences. The animals were anesthetized and then sacrificed by cervical dislocation. Animals were randomly classified into six groups of six; in the form of experimental groups, non-radiation control groups, and radiation control groups As follows:

1. The control group (no radiation and probiotic consumption).

2. without radiation, with the use of Lactobacillus Casei probiotics.

3. Radiation and use of Lactobacillus Casei.

4. No radiation, with probiotic consumption of Lactobacillus acidophilus.

5. Pollution and use of Lactobacillus acidophilus.

6. With radiation-without probiotics, test 124 groups and control groups consumed probiotics as gavage for 28 working days and standard food, respectively.

\section{Drug Preparation}

As each gram of every bacterium $\mathrm{CFU} / \mathrm{g}$ (. So, for each animal, the calculated equivalent dose of the drug was dissolved in $1 \mathrm{ml}$ of PBS buffer with a pH of about 7.2, Followed by garaging for three times a day for Lactobacillus Casei and once a day for Lactobacillus acidophilus. It was also gavaged at the same level as the PBS buffer for the control group without medication.

\section{Irradiation}


At the end of 28thworking day, all groups were exposed immediately after anesthesia, at the Department of Radiation therapy, Cancer Institute, Imam Khomeini Hospital Complex in Tehran, Radiation was performed using a machine with the dose and dose rate of $2 \mathrm{~Gy}$ and $100 \mathrm{cGY} / \mathrm{min}$ respectively. At the same time, FOV was set to $36 \times 36$ and SSD was $80 \mathrm{~cm}$.

\section{Tissue extraction}

Immediately after exposure, the animals were transferred to the Animal lab of the Tehran University of Medical Sciences and were Dissected By cervical dislocation method, under ethical considerations. After extracting the testicle, it was placed in a 2.5 microtube and transferred immediately to the nitrogen tank. Samples were stored at $-80^{\circ} \mathrm{C}$ until the total RNA was extracted.

\section{Total RNA Extraction from Testicular Tissue}

Firstly, the tissue was removed from liquid nitrogen $.1 \mathrm{ml}$ of Trysol was added to the microtubule containing chopped tissue. Vortexing of cells was then performed to make the sample wholly lysed. In the subsequent stage, incubation was done either at the temperature of the room or by placing on the ice. The next step was phase separation, which included: 1) adding 200 landa cold chloroform. 2) shaking for 15 seconds and 3 ) incubation on $4 \mathrm{C}$ ice.

The microtube was centrifuged in a refrigerated centrifuge machine for 15 minutes at a temperature of $4^{\circ}$ $\mathrm{C}$ and $12000 \mathrm{rpm}$. The supernatant was carefully is separated RNAs-Free $1.5 \mathrm{ml}$ tube at 12,000 rpm for $15 \mathrm{~min}$ centrifuges at a temperature of $4^{\circ} \mathrm{C}$. After the supernatant was poured into a new microtube, the same amount of isopropanol was added to be slowly mixed in the next stage. The centrifuge was then run at 12,000 rpm for 15 minutes at $4{ }^{\circ} \mathrm{C}$. after that, we removed the supernatant and added $1 \mathrm{ml}$ of cold ethanol $75 \mathrm{ml}$. In next step, the centrifuge was run at $7500 \mathrm{rpm}$ for 8 minutes at $4{ }^{\circ} \mathrm{C}$. Again the superficial fluid was discarded to dissolve the RNA, Which then was dried at room temperature for 5 to 10 minutes, and was suspended by adding 20 to $50 \mu$ l of RNase-free water and pipetting, before stirring the microtube for 10-15 minutes in a water bath with the incubation temperature of $55-60^{\circ} \mathrm{C}$. finally we removed four lambda, two landa from the gel and two lambda for OD reading using a nanodrop machine.

\section{Control of the concentration and quality of RNA extraction steps}

The biotech Nanodrop was applied and. The ratio of 280 / 2600D was considered as the sign of the purity of the RNA extracted. The more it became closer to 2 , the more the purity of the sample is deemed to be acceptable. Moreover, the 230 / $2600 \mathrm{D}$ ratio is regarded as the extraction of RNA contamination with the kit. Likewise, being closer to 2 is also more desirable. Ultimately, to assess the quality of RNA, it was extracted using $1 \%$ agarose gel electrophoresis and stained with ethidium bromide.

\section{cDNA synthesis}

Hprt was used for the quality control of RNA extraction processes and CDNA synthesis. The samples which were contained a copy of hprt were regarded as positive samples for the next steps. Master mix is 
then poured into every Micro USB, and following that one microgram of RNA extracted tube is used. RNA sample can be calculated based on the concentration of the sample to be poured into microtubes in the later step. All steps were performed on the ice. The tubes were placed in a thermocycler, and the cDNA synthesis was performed according to the Kit Takara instruction and according to the following table. Then cDNA was synthesized in a freezer $-20^{\circ} \mathrm{C}$.

\section{Primer}

The primer for Bax, Bcl2, caspase3 genes as well as hprt used in this study was based on the above table principles, The primers were designed using the NCBI and the Gene Runner software, and were developed by Sinacolone with OD 2. According to the Sinacolone protocol, Primers were diluted and elaborated as follows:

First, the appropriate amount of sterile distilled water was added to the primer, to reach a focus of 100 $\mu \mathrm{m}$. Then, for 5 minutes, they were incubated at room temperature. To obtain a concentration of $10 \mu \mathrm{M}$, again, $90 \mu$ sterilized distilled water was added to a ten $\mu \mathrm{L}$ primer. The optimal focus of the introduction for these reactions is one $\mu \mathrm{m}$.

\section{Steps to Real-Time PCR}

In the beginning, the ingredients were removed from the freezer to thaw slightly at room temperature. Subsequently, according to the instructions, the ingredients were carefully mixed, and after adding every one of them, we spin slightly to ensure that it is well mixed. The reaction volume is $20 \mu \mathrm{L}$. Streeps $(0.1$ microtubes) were placed carefully and by using pansies in the Cool Box, which were removed out of the freezer. The 6000 Corbett Rails Time Machine obtain the results.

\section{Statistics}

The mean of each of the variables was statistically analyzed using one way ANOVA and Tukey post hoc test. $\mathrm{P}<0.001$ was considered as meaningful level.

\section{Results}

As it can be seen in the fig. 1 that Bax gene expression has increased in each group that has been exposed to radiation compared to the non-irradiated group, which had identical diet. Moreover, Bax expression in groups that consumed LA is slightly higher than that in LK consuming groups. However, the differences cannot be regarded as significant. Notably, the LK consuming group, which has not received radiation, showed the least figure on the chart.

Having known the fact that increased expression of Bcl-2 means resistance to radiation therapy[26], From the fig. 2 we can see that bcl2 gene expression followed a different pattern in comparison with that in Bax, and the manifestation of $\mathrm{Bcl} 2$ has decreased in irradiated groups. However, $\mathrm{Bcl} 2$ expression in groups that consumed LA is again higher than that in LK consuming groups. It is also noticeable that the 
appearance of $\mathrm{Bcl} 2$ is almost identical in both irradiated and non-irradiated groups which haven't consumed probiotic drugs. Similarly, there are no significant differences among groups.

In fig.3, the results of the Caspase3 gene Illustrate that the group Which consumed LK has significantly decreased expression in comparison with both control groups either being exposed by radiation or not. In contrast, Caspase3 expression has increased in the group, which hasn't received radiation but used LA. Furthermore, groups that have been used probiotics and have been exposed to radiation also show a significant reduction in expressions. Compared to those who use probiotics but have not been exposed to radiation.

\section{Discussion}

When exposing the whole body or a part of it to radiation, the reproductive system protection from oxidative damage is of great importance[27]. Apoptosis is the leading cell death mechanism that is involved in radiation therapy[28]. Apoptosis is profoundly affected by Caspase-3, the activation of which indicates irreversible cell apoptosis[29]. Bax and Bcl-2 are apoptotic and anti-apoptotic proteins, respectively, and the ratio of those two proteins determines the occurrence of cell apoptosis[30].

In recent years, several combinations have been investigated to prevent radiation damage in radiotherapy treatments. The most important issue for selecting a radiation shield is to minimize toxicity and maximize efficacy[31]. The testosterone has an intrinsic antioxidant defense system, including a highly ordered structure of antioxidant enzymes, free radical sweeteners, and so on to maintain spermatogenesis. However, several known factors disrupt this system and increase infertility in men. Additionally, changes in testicular function due to radiation damage would result in asthenospermia, teratozoospermia, and even infertility. Radiation to this tissue can increase apoptosis in sperm cells after 24 hours. Therefore, infertility caused by pollution in planned radiation can be offset by safe radiation protection[32].

Being harmless and user-friend are the main plus points of probiotics that make these bacteria beneficial[33]. Several studies have reported reducing the side effects of the intestinal mucosa with probiotics by lowering the level of anti-inflammatory cytokines and the infiltration of neutrophils. One of these studies suggests that a mixture of probiotics would even have a more substantial antiinflammatory effect [34]. According to the results of the researches, it has been shown that these bacteria selectively induce more intense cell death in tumor cells. Probiotics such as Lactobacillus cesium and Lactobacillus acidophilus increase the ability to stimulate apoptosis in cancer cells[35]. Based on research on testicular cancer cells, Lactobacillus acidophilus and Lactobacillus chrysapatos reduced the activity of transcription of cancer genes in the testicles of mice[36].

There are studies which approved the probiotic use in the prevention or treatment of radiation injury in the intestine[37]. In experimental models of radiation injury, lactobacillus, or a mixture of it and other bacteria given to rodents before and after radiation led to decreased endotoxemia and sepsis[38]. However, the published investigations have used different doses of radiation, various animal models, and a range of 
assessed endpoints[39]. Together the results suggest that probiotics can decrease radiation-associated cell deaths. In a large study performed with the commercially available probiotic mixture on patients undergoing pelvic radiotherapy, Delia, and colleagues showed that patients taking drugs experienced lower degrees of severity[40]. In contrast, in another study conducted by Giralt et al. Both L. Acidophilus and L. Casei failed to meet meaningful endpoints inpatient groups undergoing pelvic radiation for gynecologic malignancies[41]. In research done by Aliparasti et al. apoptosis mechanisms of Wistar rats were investigated and showed an increase of the Bax/Bcl-2 ratio in the hypoxic condition[42]. Similar research carried out by Ciora et al. demonstrated the possibility of using probiotics as radioprotective agents in man was raised[43]. Cycloheximide treatment has been demonstrated by Gobe and his colleague to significantly suppress irradiation-induced cell death in the testis and kidneys of neonate rats[44]. Mansouri et al. investigated the effects of Lactobacillus Casei, Lactobacillus acidophilus, and some other probiotic drugs on patients receiving pelvic radiotherapy and reported a non-significant impact of them on blood cell counts[45]. In a research done by Khan et al. melatonin was shown as a prophylactic agent protected male reproductive system against radiation-induced injury in mice[46]. A review article was written by Mego et al. stated the fact that Probiotics might have beneficial effects on some aspects of toxicity related to anti-cancer treatment, especially radiation therapy, but more researches need to be done[47].

The results of the present study showed that there were no significant differences between being and not being irradiated control groups, for all genes studied. Additionally, no significant difference was seen in the expression of Bax gene among the studied groups. Similar to $\mathrm{Bax}, \mathrm{Bcl} 2$ is also an apoptotic gene of the mitochondrial pathway; besides, because ionizing radiation is one of the extracellular stimuli of the path of apoptosis, as expected, the radiation Had an insignificant effect on the internal path of apoptosis, or the same mitochondrial pathway. According to the results of similar studies, Radiation has been shown to increase surface cell death Receptors, such as serine triplexine kinase (AKT1), which increases the rate of apoptosis. The results of this study demonstrated that oral administration of probiotic Lactobacillus acidophilus and lactobacillus Casei in the irradiated groups decreased cellular sensitivity. As a result, the apoptosis was significantly reduced in these specimens, by reducing the expression of the Caspase 3 gene. That is to say, this decrease in apoptosis in testicular tissue cells prevents sperm from oligo-induced radiation. Based on the results of the present study, the gamma dose of 2Gy did not make any significant difference between the control group with and without radiation. However, the considerable difference in the level of apoptosis of apoptotic genes would be associated with probiotic drugs.

\section{Conclusion}

In this research, the results of the Bax gene studies showed no significant difference in the expression of this gene among the studied groups. It can be concluded that this probiotic causes cellular stability by boosting the immune system and thus reduces apoptosis and reduces the number of sperm from radiation. This article is a part of a more extensive study by which sperm counts and morphological examination will hopefully verify the beneficial effects of these harmless bacteria. 


\section{Declarations}

\section{Acknowledgment:}

Tehran University of Medical Sciences has supported this study. Grant No: 34613

\section{Ethics approval and consent to participate:}

Rats were purchased from an Animal laboratory of Tehran University of Medical Sciences. The animals were kept at $22 \pm 2{ }^{\circ} \mathrm{C}$ and $55 \pm 5 \%$ humidity. Standard feeding, and 12-hour light/ 12-hour dark cycle were used. These animals had access to enough water and food, except the time they were taking drugs. The Ethics Committee approved the protocols used in this study of Tehran University of Medical Sciences. The animals were anesthetized and then sacrificed by cervical dislocation. Grant No: 34613

\section{Consent for publication:}

All participants included in this research gave written informed consent to publish the data contained within this study. In this study, rats were kept at $22 \pm 2{ }^{\circ} \mathrm{C}$ and $55 \pm 5 \%$ humidity. Standard feeding, and 12-hour light/ 12-hour dark cycle were used. These animals had access to enough water and food, except the time they were taking drugs. The animals were anesthetized and then sacrificed by cervical dislocation.

\section{Availability of data and material:}

The datasets used and/or analyzed during the current study available from the corresponding author on reasonable request.

\section{Competing Interests:}

We declare that we have no significant competing financial, professional, or personal interests that might have influenced the performance or presentation of the work described in this manuscript.

We have described us potential competing financial, professional, and/or personal interests in the space.

\section{Funding:}

No funding was obtained for this study.

\section{Authors' contributions:}

$\mathrm{V} \mathrm{CH}, \mathrm{O} A, \mathrm{P} \mathrm{KH}, \mathrm{E} \mathrm{M}, \mathrm{M} \mathrm{SH}$, and $\mathrm{M} \mathrm{N}$ conceived and planned the experiments. $\mathrm{V} \mathrm{CH}, \mathrm{O} \mathrm{A}, \mathrm{P} \mathrm{KH}$, and $\mathrm{M} \mathrm{SH}$ carried out the experiments. $\mathrm{V} \mathrm{CH}, \mathrm{OA}, \mathrm{P} \mathrm{G}$, and $\mathrm{M} \mathrm{SH}$ planned and carried out the simulations. $\mathrm{OA}, \mathrm{P} \mathrm{KH}$, and $\mathrm{E} M$ participated in the gathering. $\mathrm{P} \mathrm{KH}, \mathrm{O} A, \mathrm{M} \mathrm{N}$ and $\mathrm{E} M$ contributed to sample preparation. $\mathrm{V} \mathrm{CH}, \mathrm{P}$ $\mathrm{KH}, \mathrm{M} \mathrm{SH}$, and $\mathrm{O} A$ contributed to the interpretation of the results. $\mathrm{P} \mathrm{KH}$ and $\mathrm{O} A$ took the lead in writing 
the manuscript. All authors provided critical feedback and helped shape the research, analysis and manuscript. All authors read and approved the final manuscript.

\section{References}

1. Shakeri-Boroujeni A, Mozdarani H, Mahmmoudzadeh M, Faeghi F. Potent radioprotective effect of herbal immunomodulator drug (IMOD) on mouse bone marrow erythrocytes as assayed with the micronucleus test. Int J Radiat Res.2016;14:221.

2. Meistrich ML. Effects of chemotherapy and radiotherapy on spermatogenesis in humans. Fertil Steril.2013;100:1180-6.

3. Koukourakis M. Radiation damage and radioprotectants: new concepts in the era of molecular medicine. Br J Radiol.2012;85:313-30.

4. Smith TA, Kirkpatrick DR, Smith S, Smith TK, Pearson T, Kailasam A, et al. Radioprotective agents to prevent cellular damage due to ionizing radiation.

J Transl Med.2017;15:232.

5. Kumar S. Second malignant neoplasms following radiotherapy. Int J Environ Res Public Health.2012;9:4744-59.

6. Ballas LK, Elkin EB, Schrag D, Minsky BD, Bach PB. Radiation therapy facilities in the United States. Int J Radiat Oncol Biol Phys.2006;66:1204-11.

7. Lobo V, Patil A, Phatak A, Chandra N. Free radicals, antioxidants and functional foods: Impact on human health. Pharmacogn Rev. 2010;4:118.

8. Spyropoulos BG, Misiakos EP, Fotiadis C, Stoidis CN. Antioxidant properties of probiotics and their protective effects in the pathogenesis of radiation-induced enteritis and colitis. Dig Dis Sci. 2011;56:285-94.

9. Biedka M, Kuźba-Kryszak T, Nowikiewicz T, Żyromska A. Fertility impairment in radiotherapy. Contemp Oncol. 2016;20:199.

10. Johnson L, Welsh T, Varner D, Scrutchfield W, Martin M. Efficiency of spermatogenesis in animals and humans. J Anim Sci.2000;7:1-47.

11. Naz M, Kamal M. Classification, causes, diagnosis and treatment of male infertility: a review. Orient Pharm Exp Med.2017;17:89-109.

12. Meistrich ML. Hormonal stimulation of the recovery of spermatogenesis following chemo-or radiotherapy. Apmis. 1998;106:37-46.

13. Mahdavi $\mathrm{M}$, Mozdarani $\mathrm{H}$. Protective effects of famotidine and vitamin $\mathrm{C}$ against radiation induced cellular damage in mouse spermatogenesis process. Iran. J. Radiat. Res. 2011;8:223.

14. Sinno-Tellier S, Bouyer J, Ducot B, Geoffroy-Perez B, Spira A, Slama R. Male gonadal dose of ionizing radiation delivered during $X$-ray examinations and monthly probability of pregnancy: a populationbased retrospective study. BMC Public Health. 2006;6:55. 
15. Chipuk JE, Moldoveanu T, Llambi F, Parsons MJ, Green DR. The BCL-2 family reunion. Mol Cell. 2010;37:299-310.

16. Gopisetty G, Ramachandran K, Singal R. DNA methylation and apoptosis. Mol Immunol. 2006;43:1729-40.

17. Salakou S, Kardamakis D, Tsamandas AC, Zolota V, Apostolakis E, Tzelepi V, et al. Increased Bax/Bcl2 ratio up-regulates caspase- 3 and increases apoptosis in the thymus of patients with myasthenia gravis. In vivo. 2007;21:123-32.

18. Hamivand Z, Haddadi G, Fardid R. Expression of Bax and Bcl2 genes in peripheral blood lymphocytes of patients with differentiated thyroid cancer. J Med Phys. 2018;43:41.

19. Oh Y-j, Kwak M-s, Sung M-H. Protection of Radiation-Induced DNA Damage by Functional Cosmeceutical Poly-Gamma-Glutamate. J Microbiol Biotechnol. 2018;28:527-33.

20. Johnke RM, Sattler JA, Allison RR. Radioprotective agents for radiation therapy: future trends. FutureOncol. 2014;10:2345-57.

21. Kouvaris JR, Kouloulias VE, Vlahos LJ. Amifostine: the first selective-target and broad-spectrum radioprotector. Oncologist. 2007;12:738-47.

22. Hall S, Rudrawar S, Zunk M, Bernaitis N, Arora D, McDermott C, et al. Protection against radiotherapyinduced toxicity. Antioxidants. 2016;5:22.

23. Organization WH. Food safety risk analysis: A guide for national food safety authorities. 2006.

24. Parvez S, Malik KA, Ah Kang S, Kim HY. Probiotics and their fermented food products are beneficial for health. J Appl Microbiol. 2006;100:1171-85.

25. Zimmerer T, Böcker U, Wenz F, Singer M. Medical Prevention and Treatment of Acute and Chronic Radiation Induced Enteritis-Is there any Proven Therapy? A short Review. Z Gastroenterol. 2008;46:441-8.

26. Ouyang L, Shi Z, Zhao S, Wang FT, Zhou TT, Liu B, et al. Programmed cell death pathways in cancer: a review of apoptosis, autophagy and programmed necrosis. CellProlif. 2012;45:487-98.

27. Finnberg N, Wambi C, Kennedy A, El-Deiry WS. The effects of antioxidants on gene expression following gamma-radiation (GR) and proton radiation (PR) in mice in vivo. Cell Cycle. 2013;12:22417.

28. Baskar R, Lee KA, Yeo R, Yeoh K-W. Cancer and radiation therapy: current advances and future directions. Int J Med. 2012;9:193.

29. He X, Sun J, Huang X. Expression of caspase-3, Bax and Bcl-2 in hippocampus of rats with diabetes and subarachnoid hemorrhage. Exp Ther Med. 2018;15:873-7.

30. Opiela J. Apoptosis in preimplantation bovine embryos and methods used for its detection. Ann. Anim. Sci. 2009;9:3-16.

31. Moding EJ, Kastan MB, Kirsch DG. Strategies for optimizing the response of cancer and normal tissues to radiation. Nat Rev DrugDiscov. 2013;12:526. 
32. Popa-Wagner A, Mitran S, Sivanesan S, Chang E, Buga A-M. ROS and brain diseases: the good, the bad, and the ugly. Oxid Med Cell Longev. 2013; 2013: 963520.

33. Sanders ME, Akkermans LM, Haller D, Hammerman C, Heimbach JT, Hörmannsperger G, et al. Safety assessment of probiotics for human use. Gut microbes. 2010;1:164-85.

34. Tang Y, Wu Y, Huang Z, Dong W, Deng Y, Wang F, et al. Administration of probiotic mixture DM\# 1 ameliorated 5-fluorouracil-induced intestinal mucositis and dysbiosis in rats. Nutrition. 2017;33:96104.

35. Baldwin C, Millette M, Oth D, Ruiz MT, Luquet F-M, Lacroix M. Probiotic Lactobacillus acidophilus and L. casei mix sensitize colorectal tumoral cells to 5 -fluorouracil-induced apoptosis. Nutr Cancer. 2010;62:371-8.

36. Modarressi RE-V, Daneshvar M, Beigom M, Mobasheri EM. Lactobacillus acidophilus and Lactobacillus crispatus culture supernatants downregulate expression of cancer-testis genes in the MDA-MB-231 cell line.

AsianPac J Cancer Prev. 2014;15:4255-9.

37. Ciorba MA, Stenson WF. Probiotic therapy in radiation-induced intestinal injury and repair. Ann N Y Acad Sci. 2009;1165:190-4.

38. Seal M, Naito Y, Barreto R, Lorenzetti A, Safran P, Marotta F. Experimental radiotherapy-induced enteritis: A probiotic interventional study. J Dig Dis. 2007;8:143-7.

39. Demirer S, Aydıntug S, Aslım B, Kepenekci I, Sengül N, Evirgen O, et al. Effects of probiotics on radiation-induced intestinal injury in rats. Nutrition. 2006;22:179-86.

40. Salminen E, Elomaa I, Minkkinen J, Vapaatalo H, Salminen S. Preservation of intestinal integrity during radiotherapy using live Lactobacillus acidophilus cultures. Clin Radiol. 1988;39:435-7.

41. Giralt J, Regadera JP, Verges R, Romero J, de la Fuente I, Biete A, et al. Effects of probiotic Lactobacillus casei DN-114 001 in prevention of radiation-induced diarrhea: results from multicenter, randomized, placebo-controlled nutritional trial. Int J Radiat Oncol Biol Phys. 2008;71:1213-9.

42. Aliparasti MR, Alipour MR, Almasi S, Feizi H. Ghrelin administration increases the Bax/Bcl-2 gene expression ratio in the heart of chronic hypoxic rats. Adv Pharm Bull. 2015;5:195.

43. Ciorba MA, Riehl TE, Rao MS, Moon C, Ee X, Nava GM, et al. Lactobacillus probiotic protects intestinal epithelium from radiation injury in a TLR-2/cyclo-oxygenase-2-dependent manner. Gut. 2012;61:829-38.

44. C. GOBE BH, J. LEIGHTON, DJ ALLAN, G. Radiation-induced apoptosis and gene expression in neonatal kidney and testis with and without protein synthesis inhibition. Int J Radiat Biol. 1999;75:973-83.

45. Mansouri-Tehrani H-A, Rabbani-Khorasgani M, Hosseini SM, Mokarian F, Mahdavi H, Roayaei M. Effect of supplements: Probiotics and probiotic plus honey on blood cell counts and serum IgA in patients receiving pelvic radiotherapy. J Res Med Sci. 2015;20:679.

46. Khan S, Adhikari JS, Rizvi MA, Chaudhury NK. Radioprotective potential of melatonin against 60 Co Y-ray-induced testicular injury in male C57BL/6 mice. J Biomed Sci. 2015;22:61. 
47. Mego M, Holec V, Drgona L, Hainova K, Ciernikova S, Zajac V. Probiotic bacteria in cancer patients undergoing chemotherapy and radiation therapy. Complement Ther Med. 2013;21:712-23.

\section{Tables}

Table 1. Materials for Synthesis of CDNA

\begin{tabular}{ll} 
ingredients & Quantity $(\mu \mathrm{l})$ \\
\hline RT Buffer $(5 \mathrm{x})$ & 2 \\
\hline Primer $(50 \mu \mathrm{M})$ oligo dT & 0.5 \\
\hline Primer: Random Hexamer $(100 \mu \mathrm{M})$ & 0.5 \\
\hline Reverse Transcriptase Enzyme & 0.5 \\
\hline Sterilized water treated with DEPC* & The final volume is 10 \\
*Diethyl pyrocarbonate $(\mathrm{DEPC})$ is used in the laboratory to inactivate RNase enzymes in water and on \\
laboratory utensils.
\end{tabular}

Table 2. Thermocycler Device Program for Reverse Transcription Reaction

\begin{tabular}{lll}
\hline The type of reaction & Temperature $\left({ }^{\circ} \mathrm{C}\right)$ & Time $(\mathrm{min})$ \\
\hline Synthesis of single stranded DNA & 37 & 15 \\
\hline Enzyme inactivation & 85 & 5
\end{tabular}

Table 3. Characteristics of primers

\begin{tabular}{ll} 
Sequences $(5-3)$ & Primer \\
\cline { 1 - 1 } F:AGCTGGACTGCGGTATTGAG & Caspase-3 \\
\cline { 1 - 1 } R:ATGGCGCAAAGTGACTGGAT & \\
\cline { 1 - 1 } F: GGCGATGAACTGGACAACAA & Bax \\
\cline { 1 - 1 } R: CAAAGTAGAAAGGGCAACC & \\
\cline { 1 - 2 } F: GGTGAACTGGGGGAGGATTG & Bcl2 \\
\cline { 1 - 1 } R: GCATGCTGGGGCATATAGT & \\
\end{tabular}


Table4. Materials for Real Time PCR

\begin{tabular}{lll}
\hline Materials & Volume $(\mu \mathrm{l})$ & Final concentration \\
\hline Master Mix 2X & 10 & $\mathrm{X} 1$ \\
\hline CDNA & 2 & $\mathrm{ng} /$ reaction $100^{3}$ \\
\hline$\mu \mathrm{M} 10$ forward primer & $8 / 0$ & $\mu \mathrm{M} 4 / 0$ \\
\hline$\mu \mathrm{M} 10$ reverse primer & $8 / 0$ & $\mu \mathrm{M} 4 / 0$ \\
\hline water RNase- Free & $4 / 6$ & -
\end{tabular}

Figures

\section{bax expression}

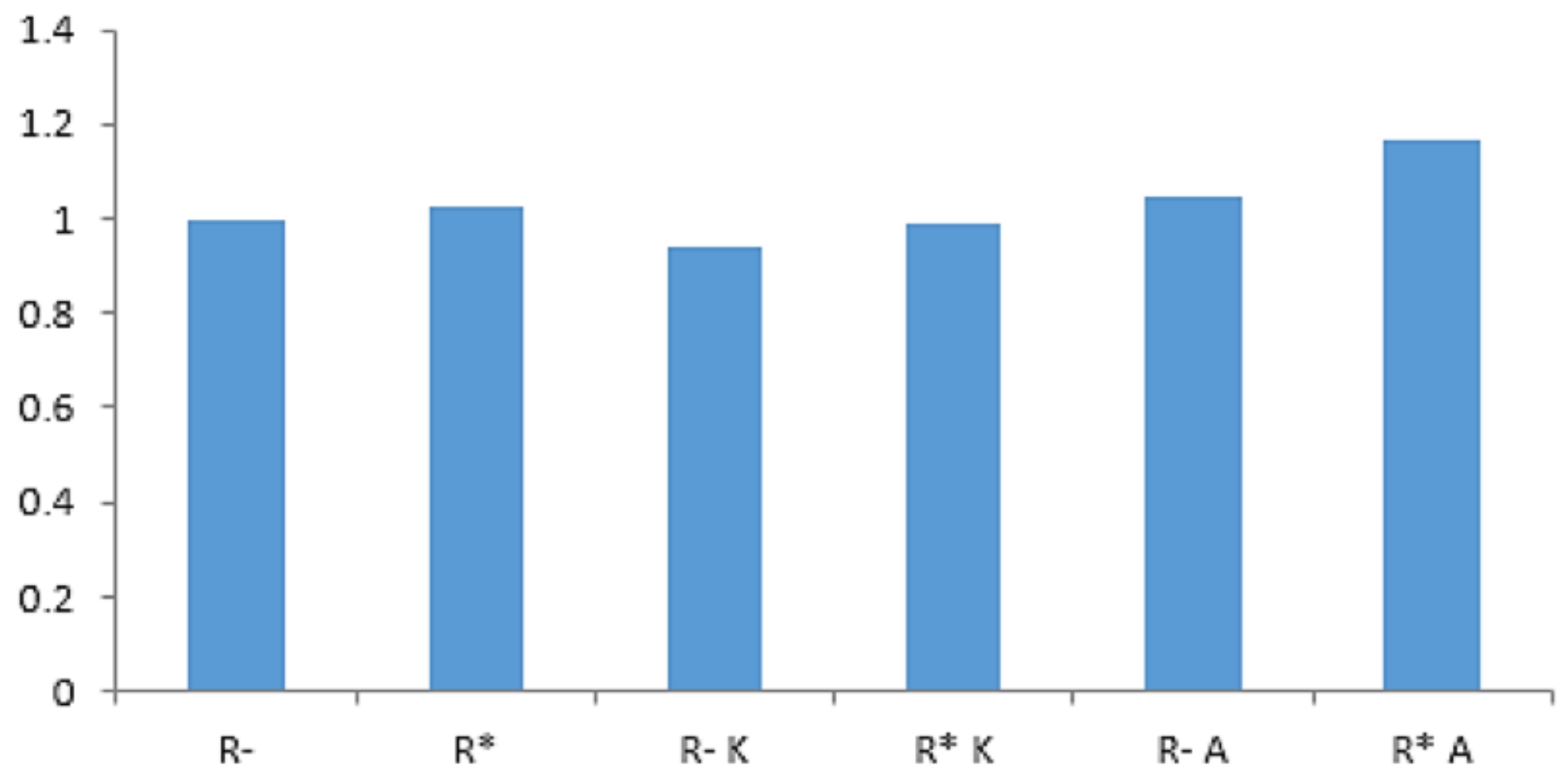

Figure 1

The diagram represents the expression of the Bax gene in the studied groups. In the horizontal axis of this chart, $\mathrm{R}$ * means radiation, $\mathrm{R}$ means non-radiation, $\mathrm{A}$ means the probiotic drug Lactobacillus acidophilus and $\mathrm{K}$ also refer to the probiotic drug Lactobacillus Casei. 


\section{Bcl2 Expression}

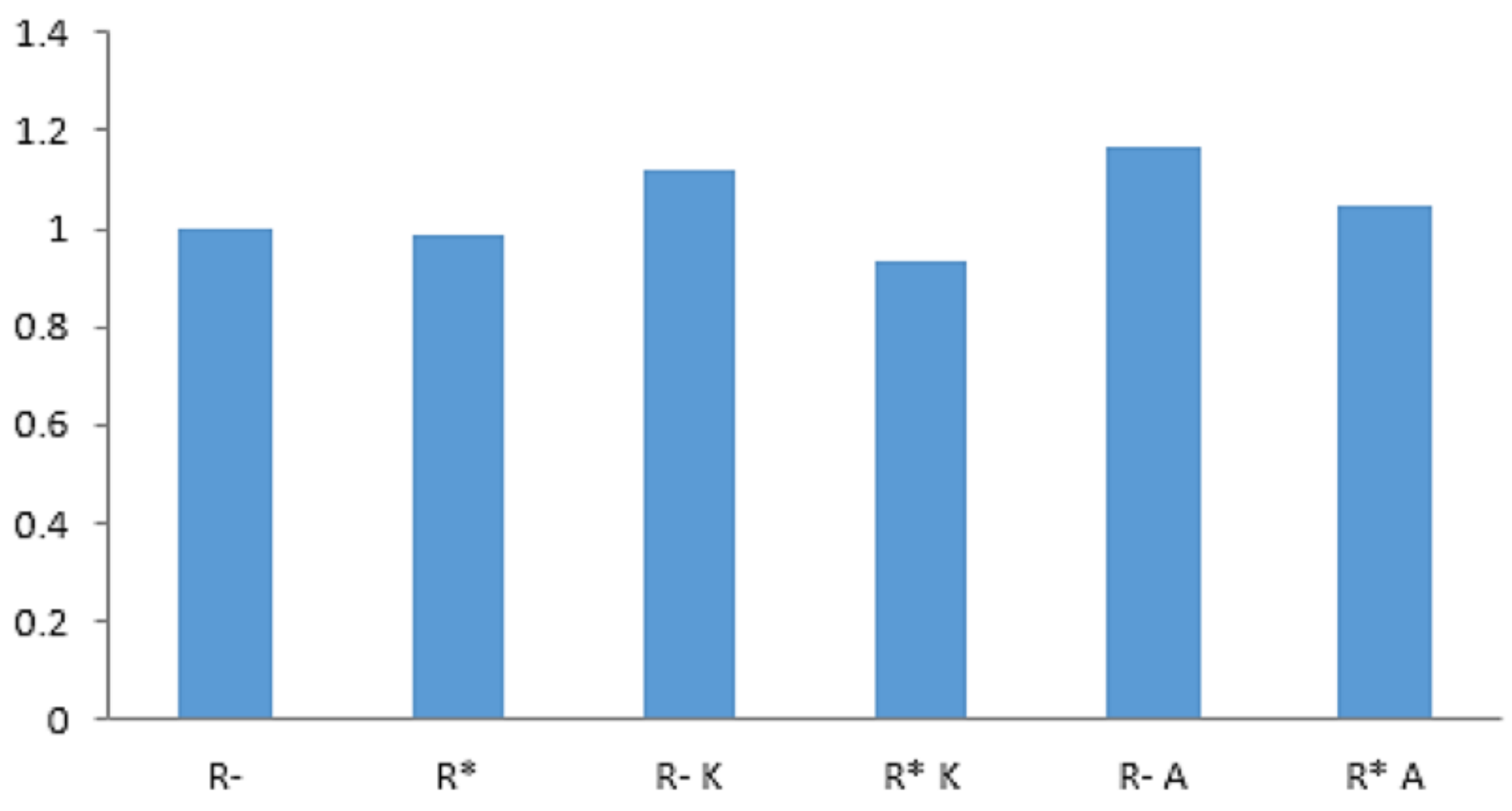

Figure 2

The graph shows the expression of the Bcl2 gene in the studied groups. In the horizontal axis of this chart, $\mathrm{R}$ * means radiation, $\mathrm{R}$ means non-radiation, A means the probiotic drug Lactobacillus acidophilus, and $\mathrm{K}$ also refer to the probiotic drug Lactobacillus Casei. 


\section{Casp3 Expression}

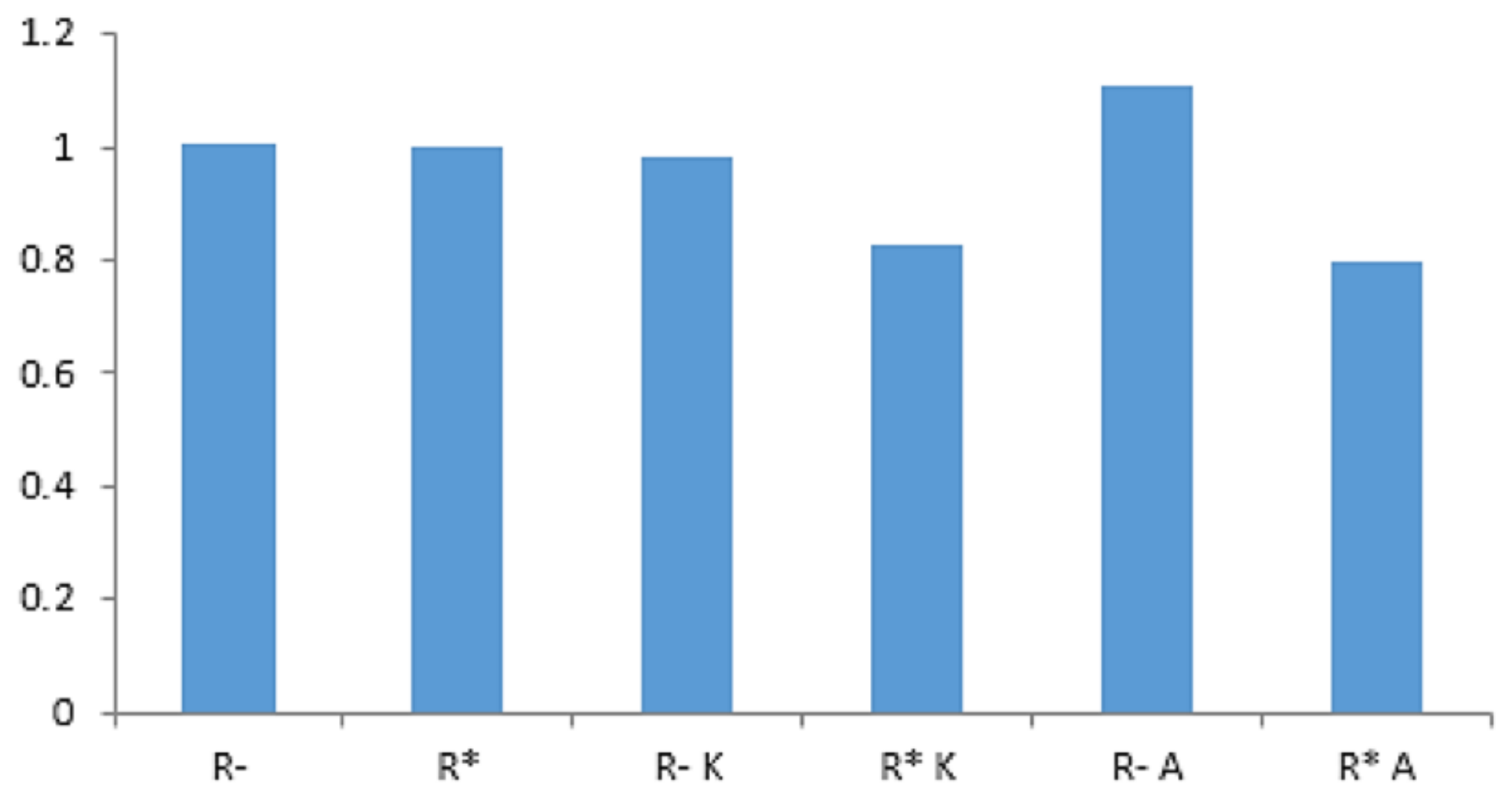

Figure 3

Shows the expression of Caspase3 gene expression in the studied groups. In the horizontal axis of this diagram, $\mathrm{R}$ * means radiation, $\mathrm{R}$ - meaning no pollution, $\mathrm{S}$ denotes the probiotic drug Bacillus acidophilus, and $\mathrm{K}$ also refers to the probiotic drug Lactobacillus Casei. 